\title{
63-The textual analysis of "The Tell- Tale Heart” by Edgar Allan Poe
}

\section{Havva FETTAHOGLU1}

APA: Fettahoğlu, H. (2022). The textual analysis of "The Tell- Tale Heart" by Edgar Allan Poe. RumeliDE Dil ve Edebiyat Araştırmalar Dergisi, (26), 1014-1023. DOI: 10.29000/rumelide.1074148.

\begin{abstract}
A text, as distinct from a sentence, can be defined as a literal use of language. Text is the unit of communication, and for a piece of language to be a text, it must be produces for a communicative purpose. Every sentence in the text is loaded with communicative tools such as transferring information, conveying attitudes or feelings, presenting facts. Seven standards of textuality which are cohesion and coherence as a text oriented and acceptability, informativity, situationality, intentionality and intertextuality as a context oriented that helps to conduct this purpose. A text is considered as a communicative if it meets these properties otherwise it called non-text. (Widdowson, 2007). In this study, how the meaning of a short story is built through seven textuality standards is explained. Thus, "The Tell-Tale Heart" which had been written by Edgar Allan Poe is analysed in this research within the context of the seven textuality requirements. In this research qualitative research method conducted to explain the standards in the text. In the research, the text was examined in detail first in terms of cohesion and then in terms of coherence. In addition, the text was examined in detail according to other criteria. As a result of the examinations, it has been observed that the examined text complies with the properties of both cohesive and coherence.
\end{abstract}

Keywords: Text, seven standards of textuality, short story, textual analysis

\section{Edgar Allan Poe'nun Gammaz Yürek’in metin analizi}

\section{Öz}

Metin, cümleden farklı olarak, dilin gerçek kullanımı olarak tanımlanmaktadır. Metin bir iletişim birimidir ve yazılı ya da sözlü herhangi bir dil parçasının metin olarak kabul edilmesi için iletişimsel amaç için üretilmiş olması gerekmektedir. Her bir cümle bilgiyi aktarma, tutum ve duygu aktarma, olgu sunma gibi iletişimsel amaçlar yüklenir. Metin odaklı olan bağdaşıklık ve tutarlık; bağlam odaklı olan kabul edilirlik, bilgisellik, durumsallık, kabul edilebilirlik ve metinlerarasılık gibi yedi metinsellik ölçütleri bu amacı oluşturmaya yardımcı olmaktadırlar. Bir metnin iletişimsel olarak kabul edilebilmesi için bu özellikleri barındırması gerekmektedir, aksi durumda metin olarak kabul edilemez. (Widdowson, 2007). Bu bilgilerden yola çıkarak, bu çalışmada kısa hikayede metinsellik ölçütler yoluyla anlamın nasıl oluşturulduğu incelenmiştir. Kısa hikaye olarak Edgar Allan Poe'nun kaleme aldı̆̆ı "The Tell-Tale Heart" adlı kısa hikaye seçilmiştir ve bu ölçütler bağlamında incelenmiştir. Araştırma nitel araştırma yöntemi kullanılmıştır. Araştırmada metin ilk olarak bağdaşıklık ve daha sonra tutarlılık bakımından incelenmiştir. Ayrıca, metinde diğer ölçütler de detaylı bir şekilde incelenmiştir. İncelenen metinin yapılan incelemeler sonucunda hem dilbilgisel olarak bağdaşıklık hem de anlamsal olarak tutarlılık ölçütlerine uygun olduğu gözlemlenmiştir.

YL Öğrencisi, İstanbul Aydın Üniversitesi, Edebiyat Fakültesi, İngiliz Dili ve Edebiyatı (İstanbul, Türkiye), havvafettahoglu@stu.aydin.edu.tr, ORCID ID: oooo-0003-1810-3668 [Araştırma makalesi, Makale kayıt tarihi: 02.01.2022-kabul tarihi: 20.02.2022; DOI: 10.29000/rumelide.1074148]

Adres $\mid$ Address

RumeliDE Dil ve Edebiyat Araştırmaları Dergisi Osmanağa Mahallesi, Mürver Çiçeği Sokak, No:14/8 Kadıköy - İSTANBUL / TÜRKIYE 34714 e-posta: editor@rumelide.com RumeliDE Journal of Language and Literature Studies Osmanağa Mahallesi, Mürver Çiçeği Sokak, No:14/8 Kadıköy - ISTANBUL / TURKEY 34714 tel: +90 5057958124, +902167730616 phone: +90 5057958124, +902167730616 
Anahtar kelimeler: Metin, metinsellik ölçütleri, kısa hikaye, metin analizi

\section{Introduction}

It is insufficient for language analyses to remain at the sentence level and linguistics studies have turned to beyond sentence studies. Thus, the concept of text has begun to gain importance in linguistics. This orientation has led to the emergence of text linguistics, which aims to remove the text from the sentence level and treat it as a whole. Text linguistics is a field of linguistics that investigates the criteria that texts should carry and determines the criteria for texts to be text. Thus, it describes the general conditions and rules of text formation and tries to explain their importance for understanding the text (Özkan, 2004).

Linguists make different definitions of exactly what a text is? Hartman and Allison (1996) define text as an idea or experience expressed in written form while Widdowson defines it an actual usage of language and he added that, any piece of language identified as a text as soon as it has been produced for a communicative purpose (2007). The fact that the literary text has an integrity, led to research what the criteria revealing the integrity are and their nature. De Beaugrande and Dressler (1981), who focused on the functions of the texts, see the text as a communication-related act that fulfils the structure and regulatory elements of the text, and collects the criteria that make up the textuality in order for a language product to be a text and to provide a healthy communication (Kılıç, 2002). In terms of linguistics, the text that is lack of any of these criteria, the communication of the text will not be healthy and the text that has no communication value will not be accepted as a text. This purpose is an essential sight of a text because, it is the connection between the reader and the text. The connection is the transformation of meaning and intention of the author to the reader, who are both party of a text. If a text is not communicative, its reader will not realize the meaning and intention of it and called non-text (Beaugrande \& Dressler,1981).

These criteria are cohesion, coherence, intentionality, acceptability, informativity, situationality and intertextuality that called seven standards of textuality important elements for comprehend the text which presents the meaning. Cohesion is the relationship between concepts in a text. It deals with the grammatical rules by which words are connected to each other to form sentences and sentences to form a larger unit, the text. Coherence is defined as the relationship between sentences and paragraphs. Intentionality is the ability of the author to reveal the message he wants to convey to the reader in a text. Acceptibility, is about the situation in which the reader presents this thought clearly and comprehensibly as a result of the author's revealing his purpose. Situationality is the appropriate description of the subject of the text according to the audience it addresses and the purpose it wants to achieve. Informativity is the situation in which the text presents new and interesting information to the reader. As for intertextuality, according to Kristeva, who used this concept for the first time, each text is formed by melting and transforming another text within itself. In the most general sense, intertextuality refers to the explicit or implicit relations of a text or a group of texts with other texts. (Bal et all., 2014). Written text is crucial factor to convey meaning to the reader and by means of it, writers can express their thoughts and opinions and share values. (Crowhurst,1990).

In a well- written text, reader have to understand the ideas of the author and the message that is given. Therefore, the main focus of this study is linguistic analysis that is focused the seven standards of textuality in written text, short story. Short story is a sort of written material that is an integral aspect of a work of art. It transmits meaning in the same way that other text styles do, in which the writer tells a

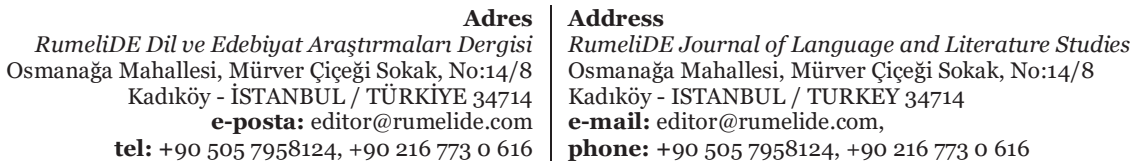


lot of information in a few sentences. As a result, the writer employs all of the language's potential, including literary arts, metaphors, symbolic language, word meanings, and so on (Torusdağ, 2018). Poe, who is the father of short story, defines the short story as a short narrative that can be told or read in one sitting. It means first the written text which called story should be short and it needs to have enough coherence to hold the reader's attention from start to finish (Lawrence, 1917). The best way to reveal the coherent is to examine the text according to its textual standards according to De Beaugrande and Dressler's theory, Seven Standards of Textuality (cohesion, coherence, intentionality, acceptability, informativity, situationality, intertextuality). In this research the short story of Edgar Allan Poe, "The Tell- Tale Heart" will be examine by considering these standards.

“The Tell-Tale Heart” was written by Edgar Allan Poe, the father of short story, and published in 1843. It is a story of an unnamed individual. The language is monologue which is dramatically written from the point of someone who has executed a homicide and fights with his insanity. In the story narrator cannot stand the pale blue eye of old man that lives with him. The story consists of four pages and fifteen paragraphs. In the story, Poe achieves an anxious and suspenseful impact and allows readers to slink inside the criminal's head (Amir, 2017).

\section{Literature review}

Text is a communication event that fits seven textuality requirements, which are cohesion, coherence, intentionality, acceptability, informativity, situationality, intertextuality, and it is not considered as a communicative if doesn't meet these seven standards. With the help of these standards, we realize how events are linked to one another: by cohesion (syntactic relations); coherence (cognitive interactions in the story); acceptability and intentionality (the reader's and writer's responses to the story); informativity (information transmission); situationality (setting); and intertextuality (the interdependency of other texts) (Mikhchi, 2011).

A well-written text includes two important features that facilitate its interpretation during the reading: coherence and cohesion (Tannen, Hamilton \& Schiffrin, 2015). Cohesion is a property that concerns how the units of surface text are mutually connected in a sequence. Halliday and Hasan (1976) believe that cohesion is linked to the semantic feature. They emphasize the importance of strong bonds which are grammatical cohesion; conjunction, substitution, ellipsis, and, references and lexical cohesion; reiteration, synonymy, antonym, hyponymy, meronymy, and collocation (Halliday and Hasan, 1976).

One of the grammatical cohesion is references according to Halliday and Hasan that is occur when information about the identity of a particular object, person, or class of thing is retrieved from the text (1976). Its role in cohesion lies in the possibility of achieving continuity whenever the same object, person, or class of things is evoked in the text more than once (Tincheva, 2012). The other cohesive device is ellipsis which means the omission of an item. It contributes to the compactness and effectiveness of the text. The complete structure takes place before the elliptic one. (Beaugrande \& Dressler 1981). Another definition of Halliday and Hasan about cohesive device is substitution, replacement of one item by another in order to conduct cohesion in the text (1976). Ellipsis and substitution are made in three different ways; verbal, nominal and causal ellipsis and substitution. The word substituted or subtracted is called nominal if it is a noun, verbal if it is a verb, or causal if it is a complete sentence. Lastly, conjunction is also a cohesive device that link words, phrases and clauses with the conjunctive devices and shows the relationship among events and situations (Beaugrande \& Dressler (1981:71). While doing this, objects or sentences in the same group are combined with additive

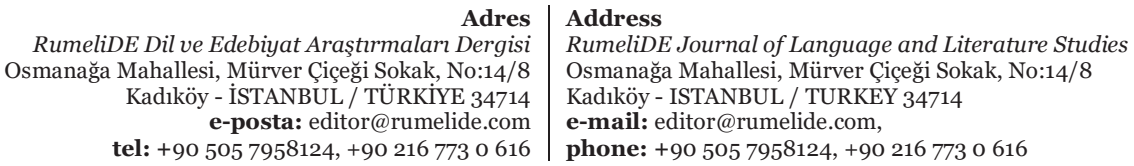


conjunctions, different groups and sentences with adverse conjunctions, causal conjunctions in causeeffect sentences and temporal conjunctions in sentences indicating the sentences relations.

Lexical cohesion, which is the another cohesive device, is a guide to the organization of the flow of ideas in the text. When word groups with related meanings are followed, it is seen which semantic fields are used, to what extent and in which patterns (Klebanov, Diermeier \& Beigman, 2008). It constructs the cohesion through vocabulary selection (Güzel \& Kılıç, 2019). The two types of lexical cohesion are reiteration and collocation. Reiteration in a text is done by using the same words more than once, using similar words with the same meaning or using words with close meanings, and sometimes using antonyms. Collocation, which dictionary meaning is a word or phrase that is used always with the another words or phrase not be excepted from the meaning.

Coherence is the other major important standards in textuality. It concerns how the components of the textual way are connected with meanings. Every text is a context for itself and coherence means every text hangs together, makes sense rather than jumble of sentences. There are different opinions among linguists about coherence as well as cohesion. According to Mikhchi (2011), a text has an essential complement that functions as a guidance for the reader while they read the text. This complement fills in the gaps in the reader's knowledge of specific information. Understanding the text clearly and definitely is an important factor for the reader. Coherence is a semantic feature of discourse that is formed through the interpretation of each sentence according to the interpretation of other sentences. According to Crystal (2011) coherence means the main principle of organization that is supposed to take into account the functional commitment underlying a spoken or written language (Wang \& Guo, 2014). It can conclude that coherence involves some factors such as language users' knowledge of the world, the interpretation they make, and the assumptions they hold. In addition, Reinhart (1980) defines coherence as a semantic and grammatical link between discourse and context. According to him, the text should be related to the context, the sentences should be related to each other, and the sentences should be related to the topic. Although it is thought that this definition is not different from the definition of cohesion, according to De Beaugrande and Dressler (1981), they are two different concepts. Coherence deals with the text in grammatical terms, while coherence deals with the deep meaning of the text (Wang \& Guo, 2014).

Although cohesion and coherence are essential for forming a text, they are not considered sufficient. In order to create a text that has cohesive and coherence integrity, it must also have other textual properties such as intentionality, acceptability, informativity, situationality and intertextuality. (Çakır, 2020). The author doesn't create a text in vain and aimlessly and has a purpose and expresses own words accordingly. Intentioanlity is the concept that is focused the intention of the author wants to convey to the reader. The writer should form a text in order to contribute some objectives and the receiver should accept these objectives. The text called communicative if this connection possible between the parties of the text (Juma'a, 2019). To describe acceptability which is other standards of textuality, Beaugrande \& Dressler (1992) maintains that it is the approach of recipient of a text in communication. The type and design of the text created should be suitable for the social and cultural environment and the person. The fourth standard is informativity which is used to determine to what extent a knowledge is new or given knowledge for recipients (Beaugrande \& Dressler, 1981). It is a concept related to how much new information the topic or message of the text contains for the reader, and how much is known beforehand. In order for a text to be informative, it depends on giving new knowledge based on the information that the reader already knows. In informative text, reader can make a connection between previous knowledge while getting the new ones. Situationality is another standard that is required in a text. In

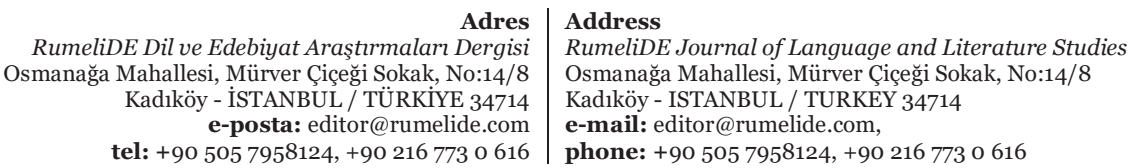


fact, to comprehend the situationality of a text, reader must first understand where it took place and what role it played in the situation. Each text should be examined by considering the time, place and situation in which it was written. Knowing the place and purpose of the text's recurrence in a circumstance is critical to assessing its situationality (Mikhchi, 2011). Lastly, Intertextualtiy is the last standard that deals with factors that render a writing reliant on prior knowledge of one or more already seen writings. According to Plato, each text is the repetition of another text in the universe (Alfaro, 1996). There is always another word in a word and another text in a text, the text is not independent. One text must refer to another text that shares the same characters whether it is spoken or written, formal or informal (Juma'a, 2019). The writer must have referred to another text that is related to the topic while creating a text. The seven standards that mentioned above are crucial to create a well- written text and conduct communication between the author and reader.

\section{Method of research}

Qualitative technique will be employed in this research in order to analyse word, phrases and sentences in the short story in terms of seven standards of textuality. The study conducted in several steps. Firstly, the story downloaded from internet and secondly it is read in detail. Then, the text has been examined in detail in terms of cohesion and coherence, which is the most important of the mentioned standards. After these details emerged, the text was examined by considering the other standards that should be in the text. Each standard reviewed in the text is explained under separate headings. Lastly, the results and opinions that emerged as a result of the examination are summarized in the conclusion section.

\section{Analysis of seven standards of textuality}

\section{Cohesion}

In the story, cohesive devices were used to form the cohesion of a text. To construct cohesion, personal references are used in the text. "he" refers to the old man who is wanted to be murdered by the narrator and "you" refers to the reader. "it" in "pull it to pieces to eat" refers to the dead body to form cohesion but "it" in "it's true" don't used for cohesion. In the text, we can also see some possessive determiners such as "my" in "my mind", "my back", "my body" refers to the narrator, and "their" in "their smiles" refers to the policeman. Demonstrative reference is another type of reference that is used in the text. "That" in "why do you say that" and "those" in "those terrible birds" which is referred to vulture in the text. That is also demonstrative references but "that" in "why do you say that" and "during all of that day" aren't from the cohesive device which focuses distance from the narrator. "There" in "I stood there quietly" and in "lying there" are demonstrative references emphasize place and "then" in "then I heard a sound", then carefully", "then I put the boards" show time that form cohesion. The last demonstrative reference in the text is "the" in "the idea" refers to murder thought, "the" in "the eye" refers to the eye of old man. Although substitution and ellipsis are not used in this story, conjunction is used to conduct cohesion. In the story we can see "and" in "I heard a sound from heaven and I heard I sound from hell", in "kill the old man and close that eye", in " and when the door opened", in " and I stood there", in "I put my hand and then my head", in " and every morning”, in " and with a warm", in " and the sound grew", in " bedcovers and held my ear", in " and put the pieces", in " cry and called police", in " and there was a strange sound", in " and still they sat and talked”, in " and the sound”, in " and still the men", in " pull up the boards and" as an additive conjunctions. However, not only and is used as additive conjunctions in the text, too in "the sound, too, became louder" and nor in "nor did I hear him" are used as an additive. The other type of conjunction is adversative that is used in the text. But in "But why do you say that", in 
"But you should have seen", in "but no", in "but the sound grew louder", in but at last", in "but why does his heart not stop beating"; Indeed, in "Indeed, the illness" is the example that used in the text. According to Halliday and Hasan, temporal and causal are also types of conjunctions (2014). First in "first entered my head", in "first I cut off"; then in "then fall upon the dead" in "and then my head", in "then I heard a sound"; when in "When the old man looked", in "when the door was opened"; now in "I was now sure", in "now he knew that", "now I could hear", in "now four o'clock"; as in "as I finished"; finally, in "Finally into the old man's bedroom" are the conjunctions that used for temporal. In addition to this, for in "for what I did", in "for it was not old"; so, in "so you think", in "so I am mad", in "so they at talking" are the causal conjunctions that used in the writing. The way similar terms are chosen to connect items is referred to as lexical cohesion. There are two forms: repetition and collocation. Repetition is made in different ways; using same word in many times like "Listen! Listen!", "seven nights" "seven long nights", "carefully" "so carefully, "sense" heard", "Louder" "louder" and "Yes!" "Yes"; and by using synonym or near synonym of the words such as "gaze" and "open"; by using superordinate of the word like "mad" "disease" and by using antonym of the word like "open" "close. These are the repetition that observed in the text but collocation is not.

\section{Coherence}

Coherence is the other significant and main part of texts. A paragraph is coherent when the reader can read sentences and the paragraph easily as a whole, rather than a random sentence (Bamberg, 1983) If the text is not understood by the reader, its communicative value cannot be told. In this sense, the story that is studied has a logical structure. From the beginning to the end, the reader can understand what the author wants to tell without experiencing any confusion of meaning. There is a harmony and order between each sentence. The fact that the sentences used in the text are connected with each other supports the next sentence of one sentence or the explanatory nature of the sentence allows the reader to understand the text easily. While doing this, the use of cohesive devices very important. The main focus of the story is the treacherous plan to commit a homicide and the feeling of guilt which is associated with this murder. Actually, the author serves this focal point with the symbols he uses and the sentences he chooses throughout the story. The fact that the main subject of the text is horror and the narrator chooses horror elements based on this, a dark room and scary eyes, show that the text provides the unity of the subject. In the words used, they are the elements that support the unity of the subject. Another feature that makes the text consistent is that time is transferred in a certain order and sequence. In the text, the man's plans to enter the old man's room at night silently for seven days and observe him, pressing the mattress on the man without thinking, are indicative of their plans and present it in a time. In addition to all these, another subject that is wanted to be told in the story is that the narrator experiences remorse for his crime. He had killed the man, but doing so for no reason, and the fact that the man's heartbeat was still ringing in his ears after the police came home, despite the man's death was his own guilt and internal feud. Hearing the man's heart beat despite his death shows the guilt he feels inside. The words, phrases, and descriptions of place are given in accordance with the main focus of the story. Coherence of a text does not only mean choosing words or sentences in accordance with the topic to be said. It is said that for a text to be coherent, the title must have a connection with the subject. The title of the story "A Tell-Tale Heart" refers to the sound of heartbeat that the narrator hears after he kills the old man. The heartbeat comes from the guilt-filled of the narrator and prompts him to surrender.

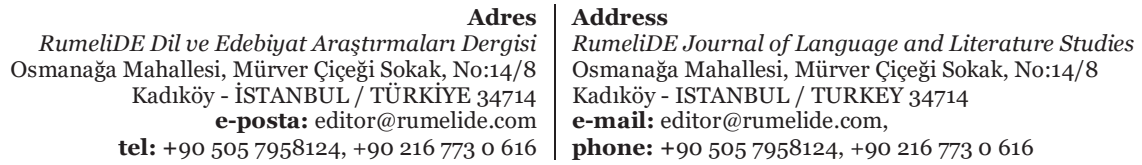
tel: $+905057958124+902167730616$

phone: +90 $5057958124,+90216773$ o 616 


\section{Intentionality}

Beaugrande \& Dressler introduce the notion of intentionality as an intention of text producers (Mikhchi, 2011). The first thing the narrator wants to tell in the text is that no matter what happens and what is said, the heart of the person knows all the truth and it is not easy to silence his conscience. The narrator's thought that the heart of the old man he killed was beating loudly between the floorboards supports this idea. Another message delivered through the text is the unreliability of the human perspective. He thinks that he has no choice but to commit this murder because of the eyes of the old man. The use of all these things in the text in a way that the reader can understand is one of the features that make the text intentionality. Moreover, Poe begins the story in capital letters and with a striking sentence, "IT'S TRUE" to attract the attention of the reader. He emphasizes that he may be sick, but that he has not lost his mind, and he repeats this over and over. In this sentence, what the writer means is that he is really not very good mentally and for this reason, at the end of the story, he tells all the crime to the police.

\section{Acceptability}

Every text is written for being accepted. Beaugrande and Dressler describe acceptability as the text attitude of recipient (1992). It means recipient must perceive a vocabulary either as a coherence (according to meaning) and cohesive (according to lexical). Acceptability of a text varies from person to person and according to the previous knowledge of the reader. Therefore, it cannot have said that the story does not comply with the rule of acceptability at all, but the brutal murder of an innocent person for no reason helps us to conclude that the story is not acceptable even if there is a feeling of internal feud and guilt after the murder. The cohesion and coherence of a text in an appropriate context is not merely a matter of linguistic signs. It can be made sense by evaluating non-text elements such as place and time, society and culture. When the place and time are considered, it is seen that the elements used in the text are at an acceptable level for the reader. it is seen that there is no light in the house, the description of a dark environment and the time when the story was written is told in connection with the story. Considering the society and culture part, it is seen that people mostly lived in rural areas at that time and most of them had a helper at home. In the story, Poe also used these elements in his story. However, the acceptability change person to person and it depends reader's perspective and their background knowledge plays important role to intend the message.

\section{Informativity}

For a text to be informative, it must contain both previous and new information by the reader. The fact that a text contains completely old information will make the text boring, and it will make it difficult to understand the text if it consists of completely new information. In the work written by Edgar Allan Poe, social problems are not touched, on the contrary, what the writer wanted to talk about was humanity. The mental states of the narrator before and after the murder reveal, Edgar Allan Poe continues to showcase the passions and human fears that unfold blindly throughout the story, while revealing the consequences of guilt and how it can exhaust itself, while also revealing the nature of human defence mechanisms. Although the social life in the story is not explicitly given, it is understood indirectly. With the word lantern used by the author, it can be deduced as a reader that light had not been invented yet at that time. In addition, it is known that in the 1800 s, American society moved to apartments in the city centre and city life was crowded and noisy with cars being used. In the light of this information, it is possible to say that the story takes place in a rural environment.

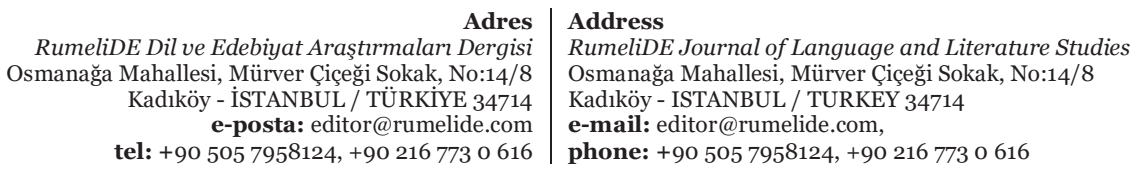




\section{Situationality}

In order to talk about the situationality, it is important to know where the events in the text take place and what their function. (Mikhchi, 2011). Poe does not deal with social problems in his stories. The main characters he chooses are characters with psychological problems who live wrongly outside the world and prefer to isolate themselves from society. The fact that the house is in a rural area and the characters live alone in the story support this. The America of the period in which the story was written was a time when factories began to be established in rural areas, but these elements are not encountered in the story.

All other elements in the text should be used in accordance with the event and situation in the text. The language and elements used in the mentioned text are proof of the situationality. The story about the murder of a man is a story that inhold gothic elements. The author has used these elements quite appropriately everywhere from the description of the room to the narration of the event. Some of these elements are that the old man's room is dark and only the old man's big eyes are visible when the door of the room is opened. In order for a text to be easily read and understood by the reader, the language used must be suitable for the theme.

\section{Intertextuality}

The Tell Tale Hearth is the first example of intertextuality. Intertextuality is the study which deals with the relationship between texts. It can be related with many fields, including literature, film, music, virtual arts and even architecture. A text cannot be written without referring to other texts written before. The writers can have influenced by other writers and used the same figures and images in their works. An example in the story would have been the comparison of the big and gaze eyes of the old man to a little adopted child's eyes in Charles Dickens' Curiosity Shop and Barnaby. In both stories, the narrators who are fascinated by their eyes, killing their opponents and the tendency to hide their corpses in the garden or under the floor are examples of intertextuality.

\section{Conclusion}

In this study, the compliance of the text examined with seven textuality criteria was investigated. During this research, grammatical and lexical devices were examined in the story. Reference, substitution, conjunctions and ellipsis are examined for as grammatical device while repetition, synonyms and collocations are examined for as lexical cohesion. These devices are very important for a text to be meaningful and essential to create communicative text. The range of vocabulary and coherence is also important to find out the deep meaning of a text. The vocabularies that are chosen are suitable for the gothic genre, which is the kind of the book.

Although cohesion and coherence are crucial part of a text, the other standards should also be in a wellwritten text. It is seen that at the end of the research, the story of Poe meets all other standards as well. Herein, the study indicates that the short story which is examined, meets these seven standards. The meaning is constructed when the story is read and the reader can piece together the puzzle and deduce the text's deeper meaning.

\footnotetext{
Adres | Address

RumeliDE Dil ve Edebiyat Arasttrmaları Dergisi Osmanağa Mahallesi, Mürver Çiçeği Sokak, No:14/8 Kadıköy - İSTANBUL / TÜRKIYE 34714 e-posta: editor@rumelide.com

RumeliDE Journal of Language and Literature Studies Osmanağa Mahallesi, Mürver Çiçeği Sokak, No:14/8 Kadıköy - ISTANBUL / TURKEY 34714 e-mail: editor@rumelide.com tel: +90 5057958124, +902167730616 phone: +90 5057958124, +902167730616
} 
1022 / RumeliDE Journal of Language and Literature Studies 2022.26 (February)

The textual analysis of “The Tell- Tale Heart” by Edgar Allan Poe / H. Fettahoğlu (pp. 1014-1023)

\section{References}

Alfaro, M. J. M. (1996). Intertextuality: Origins and development of the concept. Atlantis, 268-285.

Amir, S. (2020). Analysis of the Short Story 'The Tell-Tale Heart by Edgar Allan Poe. The Creative Launcher, 2. 596- 606. https://www.researchgate.net

Bal, M., Güven, A. Z., \& Halat, S. (2014). Examination of the Text in 5th Grade Secondary School Turkish Text Books in Terms of Standards of Textuality.

Bamberg, B. (1983). What makes a text coherent? College composition and communication, 34(4), 417429. https://doi.org/10.2307/357898

Çakır, A. (2014). Söylem analizi: ne demek istiyorsun? Palet Yayınları.

Celce-Murcia, M. and Olshtain, E. (2000). Discourse and Context in Language Teaching: a Guide for Language Teachers. NY: Cambridge University Press.

Crowhurst, M. (1990). Teaching and learning the writing of persuasive/argumentative discourse. Canadian Journal of Education/Revue canadienne de l'éducation, 348-359.

De Beaugrande, R. A. \& Dressler, W. U. (1981). Introduction to text linguistics (Vol. 1). London: Longman. https://d1wqtxts1xzle7.cloudfront.net

Güzel, S., \& Kılıç, V. (2019). The Textual Analysis of William Blake's Holy Thursday from Songs of Experience. Electronic Turkish Studies, 14(6). https://doi.org/ 10.29228

Halliday, M. A. K. \& Hasan, R. (2014). Cohesion in English (No. 9). New York, USA: Routledge.

Jakobson, R. (1960). Linguistics and poetics. In Style in language (pp. 350-377). MA: MIT Press.

Juma'a, T. R. (2019). Seven Standards of Textuality in Parents-Child Communication in an English Movie (A Discourse Study). Journal of Education College Wasit University, 2(37), 18-18. https://doi.org/10.31185/eduj.Vol2.Iss37.1105

Kılıç, V. (2002). Dilin Iş̧levleri ve İletişim: Dilbilim Açısından Kuramsal Bir Çalışma (1st ed.). Istanbul, Türkiye: Papatya Yayınları

Klebanov, B. B., Diermeier, D., \& Beigman, E. (2008). Lexical Cohesion Analysis of Political Speech. Political Analysis, 16(4), 447-463. https://doi.org/10.1093/pan/mpnoo7

Lawrence, J. C. (1917). A theory of the short story. The North American Review, 205(735), 274-286.

Mikhchi, H. H. (2011). Standards of Textuality: Rendering English and Persian Texts Based on a Textual Model. Journal of Universal Language, 12(1), 47-74. https://doi.org/10.22425/jul.2011.12.1.47

Niya, M. S. (2015). Textuality Found on the Jakarta Post in Education Section of Opinion Columns (Doctoral Dissertation, Universitas Islam Negeri Maulana Malik Ibrahim). http://etheses.uin-malang.ac.id/

Orr, M. (2010). Intertextuality. The encyclopedia of literary and cultural theory. https://doi.org/10.1002/9781444337839.wbelctv2ioo2

Özkan, B. (2004). Metindilbilimi metindilbilimsel bağdaşıklık ve Haldun Taner’in onikiye bir var adlı öyküsünde metindilbilimsel bağdaşıklık görünümleri. Çukurova Üniversitesi Sosyal Bilimler Enstitüsü Dergisi, 13(1).

Reinhart, T. (1980). Conditions for text coherence. Poetics today,1(4), 161-180. https://doi.org/10.2307/1771893

Tannen, D., Hamilton, H. E., \& Schiffrin, D. (2015). The handbook of discourse analysis. John Wiley \& Sons. https://edisciplinas.usp.br/

Tincheva, N. (2012). Halliday or De Beaugrande and Dressler: Faqs. htttps://papers.ssrn.com

Torusdağ, G. (2018). Textlinguistic Analysis of the Short Stories and Language Teaching Sample of Eveline by Joyce. Dil ve Edebiyat Araştırmalar, 18(18), 127-167. https://dergipark.org.tr

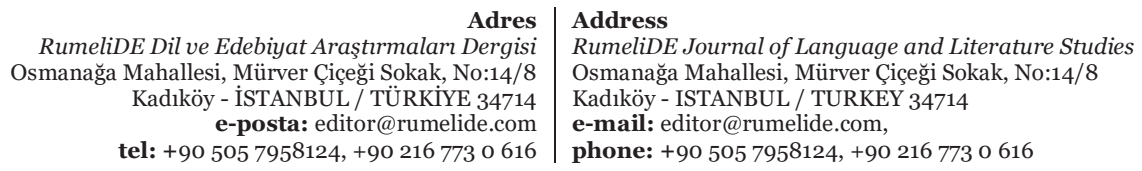


Wang, Y., \& Guo, M. (2014). A short analysis of discourse coherence. Journal of Language Teaching and Research, 5(2), 460.

Widdowson, H. G. (2007). Discourse analysis (Vol. 133). Oxford: Oxford University Press.

RumeliDE Dil ve Edebiyat Araşttrmaları Dergisi Osmanağa Mahallesi, Mürver Çiçeği Sokak, No:14/8 Kadıköy - İSTANBUL / TÜRKIYE 34714 tel: +90 5057958124,+90 2167730616
Address

RumeliDE Journal of Language and Literature Studies

Osmanağa Mahallesi, Mürver Çiçeği Sokak, No:14/8

Kadıköy - ISTANBUL / TURKEY 34714

e-mail: editor@rumelide.com

phone: +90 $5057958124,+902167730616$ 